\title{
Examination of the relationship between nursing student's internet and smartphone addictions
}

\author{
Emriye Hilal Yayan ${ }^{1}$ \\ Mehmet Emin Düken ${ }^{2}$ \\ Yeliz Suna Dağ ${ }^{3}$ \\ Ayşegül Ulutaş ${ }^{4}$
}

\begin{abstract}
Aim: The study examines the relationship between college nursing students' smartphone addiction and internet addictions.

Material and Method: The sample of this descriptive relationship-seeking study included 788 college nursing students. A personal information form, the Smartphone Addiction Scale and the Internet Addiction Scale were used as data collection tools.

Results: The participants had high smartphone and internet addiction scores. The males were more prone to exhibit addictive behavior. The addiction scores of the students who cannot stand to be away from their phones were higher. Students involved in sports and students with reading habits had lower addiction scores. A strong positive correlation was found between students' smartphone and internet addiction scores.
\end{abstract}

Conclusions: Due to the strong correlation between smartphone and internet addiction, it was concluded that further research is needed to investigate addictive behaviors, particularly for smartphone addiction.

Keywords: Smartphones; internet; addiction; nursing students.

\section{Introduction}

Developments in internet and smartphone technology have made our lives more full and fun than ever. Day by day these developments make our lives easier. Internet-enabled mobile phones make it easier to email, chat, manage personal data, reach online newspapers, get road assistance and directions through navigation and maps, access educational materials, use social media and even access health-related clinical information (Choi et al., 2014; Davey \& Davey, 2014; Jun, 2015). Smartphones lead to social and psychological behavioral consequences that affect individual and collective habits, social competencies, personality and relationships (A. King et al., 2013). The increase in the use of internet and smartphones has led researchers to study this subject. Although smartphones have significant benefits for communication, problematic use poses risks to human life. These include personal information infringements, harmful or inaccurate information, copyright infringement and psychosocial issues related to overuse (Jun, 2015; Totten, Lipscomb, Cook, \& Lesch, 2005).

\footnotetext{
1 Assist. Prof. , İnönü University, Nursing Faculty, Child Health and Disease Nursing Department, emriye.yayan@inonu.edu.tr

2 Research Assistant, İnönü University, Nursing Faculty, Child Health and Disease Nursing Department, emin.duken@inonu.edu.tr

${ }^{3}$ Research Assistant, İnönü University, Nursing Faculty , Child Health and Disease Nursing Department, yeliz.suna@inonu.edu.tr

${ }^{4}$ Assist. Prof. , İnönü University, School of Health Sciences, Department of Child Development, aysegul.ulutas@inonu.edu.tr Submitted: 2018-02-21 Published: 2018-06-05
} 
Yayan, E. H., Düken, M. E., Dağ , Y. S., \& Ulutaş, A. (2018). Examination of the relationship between nursing student's internet and smartphone addictions. Journal of Human Sciences, 15(2), 1161-1171. doi:10.14687/jhs.v15i2.5247

Internet addiction is a multidimensional syndrome with cognitive and behavioral symptoms that cause adverse social, academic and professional outcomes. Psychosocial problems (e.g., loneliness, poor social skills) lead to negative consequences due to online activities. Researchers have found a relationship between psychosocial health and internet addiction during adolescence and adulthood (F. Lin et al., 2012; Mittal, Tessner, \& Walker, 2007; S. C. Yang \& Tung, 2007; J. Y. Yen et al., 2008). Similar considerations may arise for smartphone addiction because smartphone use triggers internet use. The combination of many different features and easy internet access on smartphones facilitates the emergence of addiction (Ezoe \& Toda, 2013; Ha, Chin, Park, Ryu, \& Yu, 2008; Kwon et al., 2013). The popularity of smartphones also increases anxieties about the negative consequences of their overuse (Y. Kim et al., 2016). Studies of the overuse of smartphones report that it causes physical health problems such as musculoskeletal disorders in the hands, wrists and neck (Lee \& Seo, 2014). Health problems due to the overuse of smartphones include eye symptoms, sleep disorders, aggression and attention deficit (Y.-S. Yang, Yen, Ko, Cheng, \& Yen, 2010; Zheng et al., 2014). However, there are no established diagnostic criteria for disorders caused by excessive phone use. Whether the concept of addiction is appropriate for this situation is being discussed by researchers. On the other hand, the number of studies, clinical cases and reports supporting the fact that this phenomenon looks like addiction have rapidly increased in recent years. Several symptoms similar to addictive disorders have been shown in DSM-5 and include withdrawal symptoms (Y. Kim et al., 2016). Smartphone abuse is gradually increasing in this century. Adolescents who were using smartphones as a leisure activity have already passed to full-time use, which can be a sign of overuse and smartphone addiction (Davey \& Davey, 2014; H. Kim, 2013).

Young people who exhibit smartphone addiction characteristics suffer from deterioration in daily life, poor academic performance, worsened social relations and reduced social interaction in real life (J Kuss, D Griffiths, Karila, \& Billieux, 2014; Kwon et al., 2013). Many researchers point out that the overuse of smartphones can cause addiction. However, nothing is clear about smartphone addiction (Choi et al., 2014). The most basic feature of smartphones is that almost all applications require internet access. Smartphone and internet use have similar features.

Purpose of the research: Therefore, this study examines the relationship between college nursing students' smartphone and internet addictions and some of their features.

\section{Method}

This is a descriptive relationship-seeking study.

\section{Study Universe and Sample}

This study's population consisted of 1,125 students in the nursing department of a university in Turkey. No sampling was done, and all the students were included in the study. A survey was conducted with 788 nursing students who agreed to participate.

\section{Data Collection Tools}

The research data were collected using a Personal Information Form, the Internet Addiction Scale and the Smartphone Addiction Scale.

\section{The Personal Information Form}

This form was prepared by the researchers. It includes 12 questions concerning age, gender, working status, internet access on their smartphones, income status and smartphone use. The form consists of multiple choice and open-ended questions and can be completed in 5-10 minutes.

\section{The Internet Addiction Scale}

This present study used; developed by Griffiths the Turkish version of the internet addiction scale (IAS) and translated into Turkish and tested for validity and reliability by Canan et al. (2010). This scale originally included 36 items; however, the items incompatible with the validity and reliability study were excluded. There are 27 items in its Turkish version. The responses range from 1 to 5 ( $1=$ never, $2=$ rarely, $3=$ sometimes, $4=$ frequently, $5=$ always), and are 
Yayan, E. H., Düken, M. E., Dağ , Y. S., \& Ulutaş, A. (2018). Examination of the relationship between nursing student's internet and smartphone addictions. Journal of Human Sciences, 15(2), 1161-1171. doi:10.14687/jhs.v15i2.5247

added to obtain the total score. Score over 81 indicate internet addiction (Canan, Ataoglu, Nichols, Yildirim, \& Ozturk, 2010).

\section{The Smartphone Addiction Scale}

The smartphone addiction scale (SAS) is a Likert type scale developed by Kwon et al. (2013). There are 33 questions on this scale with options ranging from 1 point to 6 points ( $1=$ definitely no, $2=$ no, $3=$ partly no, $4=$ partly yes, $5=$ yes, $6=$ definitely yes). The lowest and highest possible scores on the scale are 33 and 198, respectively. The scale consists of seven subscales: disturbance of daily life and tolerance with 8 questions $(1,2,5,29,30,31,32,33)$, withdrawal symptoms with 7 questions $(10,11,12,13,14,15,16)$, positive expectations with 5 questions $(6,7,8,9,20)$, cyber-focused relationships with 4 questions $(21,22,23,26)$, overuse with 4 questions $(17,18,19,28))$, social network addiction with 2 questions $(24,25)$ and physical symptoms with 3 questions $(3,4,27)$. There is no cutoff point, but the higher the score on the test, the greater the risk of addiction (Demirci, Orhan, Demirdas, Akpinar, \& Sert, 2014). The adaptation of the scale to Turkish was performed by Demirci et al. (2014) with a seven factor structure similar to the original scale. The Cronbach's alpha internal consistency factor of the scale was 0.947 (Demirci et al., 2014).

\section{Data Analysis}

SPSS 18.0 software was used for the statistical analysis. The distribution of the data was examined using analytical methods (the Kolmogorov-Smirnov and Shapiro-Wilk tests). Student's $\mathrm{t}$ test and the one-way Anova test were used for data analysis because the data had a normal distribution. The data are presented as arithmetic means \pm standard deviations. Since both variables were normally distributed, the Pearson test was used for correlation analysis. The threshold for statistical significance was $\mathrm{p}<0.05$.

\section{Results}

The mean age of the students who participated in the survey was $20.80 \pm 2.67$ years. Of them, $58 \%$ were female, and $42 \%$ were male. Of them, $39.6 \%$ had sports habits, and $76.6 \%$ had reading habits. Of the students, $94.9 \%$ had phones with internet connections. The 40 participants who said that they did not have internet connections on their phones used the university's wireless internet. The majority of them did not have jobs. Of them, $26.4 \%$ had less income than their expenses, $56.3 \%$ had incomes that equaled their expenses, and $17.3 \%$ had more income than their expenses. Of the students, $66 \%$ reported that when they reached their internet quota they waited for the next month, and 34\% reported that they had reopened their internet quota by cutting other expenditures. In addition, 21.8\% reported that they started to use their phones when the phones were charged a little bit, $56.9 \%$ used their phones while charging, and $21.3 \%$ waited to charge their phones fully. None of them left their phones outside of the room while sleeping, and $82.2 \%$ left their phones at an accessible distance (under or inside the pillowcase, by their bedside, etc.), whereas $17.8 \%$ left their phones at an non-accessible distance. Of them, $77.7 \%$ checked their phones or used a phone application first thing when they woke up in the morning. It was determined that $47.7 \%$ of them used their phones during classes (Table 1).

The participants' mean score on the smartphone addiction scale was 90.58. Their mean scores on its subscales were 23.38 for disturbance of daily life and tolerance, 18.02 for withdrawal symptoms, 16.32 for positive expectations, 7.57 for cyber-focused relations, 11.53 for overuse, 5.00 for social network addiction and 8.74 for physical symptoms. Their mean score on the internet addiction scale was 68.60 (Table 2).

The mean scores on the internet and smartphone addiction scales and subscales were compared to the participants' demographic characteristics. The male students scored high except on the internet and smartphone addiction scales and the social network addiction subscale of the smartphone addiction scale. No significant difference in the social network addiction subscale was found between genders. The participants with sports habits obtained significantly lower mean scores on the internet and smartphone addiction scales and the subscales of disturbance of 
Yayan, E. H., Düken, M. E., Dağ , Y. S., \& Ulutaş, A. (2018). Examination of the relationship between nursing student's internet and smartphone addictions. Journal of Human Sciences, 15(2), 1161-1171. doi:10.14687/jhs.v15i2.5247

daily life and tolerance, withdrawal symptoms, positive expectations, cyber-focused relationships, overuse, and physical symptoms. Sports habits had no effect on social network addiction. The participants with reading habits had significantly lower mean scores on the internet and smartphone addiction scales and the subscales of disturbance of daily life and tolerance, withdrawal symptoms, positive expectations, overuse, and physical symptoms. Statistically significant differences were found between the participants who started to use their phones when they were charged a little bit, those who used their phones while charging and those who waited to charge their phones fully. The participants with less income than their expenses were determined to have the highest mean addiction score. A statistically significant difference was also found between the income groups in terms of all scales and subscales except the subscale of positive expectations. The participants who reopened their internet quota by cutting other expenditures when they reached their monthly internet quota, and those who left their phones within reach while sleeping had significantly higher internet and smartphone addiction mean scores. The participants who checked their phones or used a phone application first thing in the morning obtained significantly higher internet and smartphone addiction mean scores. The participants who used their phones during classes also had significantly higher mean scores on the internet and smartphone addiction scales and the subscales of disturbance of daily life and tolerance, withdrawal symptoms, positive expectations, overuse, social network addiction and physical symptoms (Table 3).

A strong positive correlation was found between the students' mean scores on the internet and smartphone addiction scales. A strong positive correlation was also found between their mean scores on the internet addiction scale and the subscales of disturbance of daily life and tolerance, withdrawal symptoms, positive expectations, overuse and physical symptoms on the smartphone addiction scale. A moderate positive correlation was found between their mean scores on the internet addiction scale and the subscales of social network addiction and cyberfocused relationships on the smartphone addiction scale. The lowest positive correlation was found between the mean scores on the internet addiction scale and the subscale of cyber-focused relationships on the smartphone addiction scale (Table 4).

\section{Discussion}

Smartphone use is increasing day by day and can affect important aspects of everyday life. Concerns about the negative consequences of excessive smartphone use caused by the popularity of smartphones are also growing (Y. Kim et al., 2016; C.-F. Yen et al., 2009). This study determined that male students had higher levels of smartphone and internet addiction. Other studies have also reported that males use smartphones more than females (Aljomaa, Qudah, Albursan, Bakhiet, \& Abduljabbar, 2016; Bianchi \& Phillips, 2005; Sar, 2013) and have higher levels of internet addiction (Canan et al., 2010; Erdoğan, 2015; Esen, 2010; Üneri \& Tanıdır, 2011; J. Y. Yen et al., 2008). The reason for the male students' higher mean scores on both scales is that they have a higher tendency to use technology. There are also studies showing that female students have higher levels of addiction (Joiner et al., 2012; Y.-S. Yang et al., 2010; C.-F. Yen et al., 2009). Studies have reported differences between male and female internet use patterns, stating that internet use for social purposes is more important for females while surfing on the internet is more important for males (Chen, 2012; Joiner et al., 2012; Kang, 2007). This study found smartphone and internet addiction mean scores similar to those found in the relevant literature (Billieux, Maurage, Lopez-Fernandez, Kuss, \& Griffiths, 2015; Chen, 2012; Kwon et al., 2013; Şar, 2013; Yayan, Arikan, Saban, Gürarslan Baş, \& Özel Özcan, 2016).

A study of high school students found mean scores on the smartphone addiction scale and subscales similar to this study (Çakır \& Oğuz, 2017). Recent studies have shown that the rate of internet and smartphone addiction gradually rises each year (Aljomaa et al., 2016; Çakır \& Oğuz, 2017; Jun, 2015; Y. Kim et al., 2016; Kwon et al., 2013; Y.-H. Lin et al., 2014; Yayan et al., 2016), and this study's results are similar to the literature. This study found statistically significant 
Yayan, E. H., Düken, M. E., Dağ , Y. S., \& Ulutaş, A. (2018). Examination of the relationship between nursing student's internet and smartphone addictions. Journal of Human Sciences, 15(2), 1161-1171. doi:10.14687/jhs.v15i2.5247

differences between the income groups of participants on all scales and subscales except for the subscale of positive expectations, and those with less income than their expenses had the highest mean internet and smartphone addiction scores. Koivusilta et al. (2007) found that adolescents from low socioeconomic levels spent more time using smartphones than those from high socioeconomic levels (Koivusilta, Lintonen, \& Rimpelä, 2007). This study found that students with sports and reading habits had very low smartphone and internet addiction scores. Sports and reading habits can help students to use their time more effectively and reduce addiction because these habits prevent them from spending too much time on their smartphones. This is supported by the fact that the most important effect of smartphone and internet addiction is reported to be overuse (Cao \& Su, 2007; Ezoe \& Toda, 2013; Y. Kim et al., 2016; Kwon et al., 2013; Şar, 2013; C.F. Yen et al., 2009; Zheng et al., 2014).

The levels of both smartphone and internet addiction were found to be high among the participants who left their phones within reach while sleeping, those who check their phones first thing in the morning, those who used their phones during classes, those who reopened their internet quota by cutting other expenditures and those who use their phones while charging them. Studies have mentioned a new concept, nomophobia, which refers to people who are afraid of being separated from their smartphones (Erdem, Kalkın, Türen, \& Deniz, 2016; A. L. S. King et al., 2014). A study conducted in England reported that individuals take their smartphones wherever they go, keep them at their bedside while sleeping and worry about being away from them (SecurEnvoy, 2012). An empirical study of individuals who cannot be separated from their smartphones reported that they felt being anxious and in an emotional vacuum when they were away from their smartphones (A. L. S. King et al., 2014). Studies have also reported that people who use their smartphones at night exhibit more signs of addiction (Zheng et al., 2014). Smartphones' easy access to the internet are considered to trigger this. The greatest fear of students who cannot stand to be separated from their smartphones is being unable to communicate and access information (Yildirim \& Correia, 2015). The most important feature of a smartphone its ability to communicate more cheaply than other communication tools (Valkenburg, Peter, \& Schouten, 2006). Students do not want to be separated from their phones while sleeping or awake and thus have higher levels of addiction due to overuse. A study of university students found that when they were separated from their smartphones, they exhibited anxiety symptoms that increased with their levels of excessive use (Cheever, Rosen, Carrier, \& Chavez, 2014).

This study found a high correlation between internet and smartphone addiction. A study of adolescents in Korea found a relationship between internet and smartphone addiction. It also analyzed their addiction levels from 2011 to 2014 and determined that, although their internet and smartphone addiction levels were similar in 2011, their level of smartphone addiction rapidly increased to $29.2 \%$ during the research period, but their level of internet addiction did not change significantly. The study did not examine the relationship between internet and smartphone addiction because it considered smartphone addiction an independent concept. However, smartphone addiction shares basic features with internet addiction (Jun, 2015). People should be encouraged to create their own healthy lifestyle by acquiring positive health behaviors to protect and improve their health (Tambağ, 2011).

\section{Conclusion and Recommendations}

Even if the concept of addiction is traditionally seen as involving the ingestion of substances, internet and smartphone addiction should be examined as an example of behavioral addiction. This study results will help to understand the basic features of internet and smartphone addiction and support advanced research on this subject. Further research should examine the relationship between smartphone and internet addiction in depth. 
Yayan, E. H., Düken, M. E., Dağ , Y. S., \& Ulutaş, A. (2018). Examination of the relationship between nursing student's internet and smartphone addictions. Journal of Human Sciences, 15(2), 1161-1171. doi:10.14687/jhs.v15i2.5247

\section{References}

Aljomaa, S. S., Qudah, M. F. A., Albursan, I. S., Bakhiet, S. F., \& Abduljabbar, A. S. (2016). Smartphone addiction among university students in the light of some variables. Computers in Human Behavior, 61, 155-164.

Bianchi, A., \& Phillips, J. G. (2005). Psychological predictors of problem mobile phone use. CyberPsychology \& Behavior, 8(1), 39-51.

Billieux, J., Maurage, P., Lopez-Fernandez, O., Kuss, D. J., \& Griffiths, M. D. (2015). Can disordered mobile phone use be considered a behavioral addiction? An update on current evidence and a comprehensive model for future research. Current Addiction Reports, 2(2), 156-162.

Canan, F., Ataoglu, A., Nichols, L. A., Yildirim, T., \& Ozturk, O. (2010). Evaluation of psychometric properties of the internet addiction scale in a sample of Turkish high school students. Cyberpsychology, Behavior and Social Networking, 13(3), 317-320.

Cao, F. \& Su, L. (2007). Internet addiction among Chinese adolescents: Prevalence and psychological features. Child: care, health and development, 33(3), 275-281.

Cheever, N. A., Rosen, L. D., Carrier, L. M. \& Chavez, A. (2014). Out of sight is not out of mind: The impact of restricting wireless mobile device use on anxiety levels among low, moderate and high users. Computers in Human Behavior, 37, 290-297.

Chen, S. K. (2012). Internet use and psychological well-being among college students: A latent profile approach. Computers in Human Behavior, 28(6), 2219-2226.

Choi, S. W., Mok, J. Y., Kim, D. J., Choi, J. S., Lee, J. W., Ahn, H.J., et. al. (2014). Latent class analysis on internet and smartphone addiction in college students. Neuropsychiatric disease and treatment, 10, 817 828.

Çakır, Ö. \& Oğuz, E. (2017). Lise öğrencilerinin yalnızlık düzeyleri ile akıllı telefon bağımlılı̆̆ı arasındaki ilişki. Mersin Üniversitesi Eğitim Fakültesi Dergisi, 12(1), 418-429

Davey, S. \& Davey, A. (2014). Assessment of smartphone addiction in Indian adolescents: A mixed method study by systematic-review and meta-analysis approach. International Journal of Preventive Medicine, 5(12), 1500-1511.

Demirci, K., Orhan, H., Demirdas, A., Akpinar, A. \& Sert, H. (2014). Validity and reliability of the Turkish Version of the Smartphone addiction scale in a younger population. Bulletin of Clinical Psychopharmacology, 24(3), 226-234.

Erdem, H., Kalkın, G., Türen, U. \& Deniz, M. (2016). Üniversite öğrencilerinde mobil telefon yoksunluğu korkusunun (nomofobi) akademik başar1ya etkisi. Süleyman Demirel Üniversitesi İktisadi ve İdari Bilimler Fakültesi Dergisi, 21 (3), 923-936

Erdoğan, Y. (2015). Exploring the relationships among internet usage, internet attitudes and loneliness of Turkish adolescents. Cyberpsychology: Journal of Psychosocial Research on Cyberspace, 2(2).

Esen, E. (2010). Ergenlerde internet bă̆gmhlĭğm yordayan psiko-sosyal değğskenlerin incelenmesi. DEÜ Eğitim Bilimleri Enstitüsü.

Ezoe, S. \& Toda, M. (2013). Relationships of loneliness and mobile phone dependence with internet addiction in Japanese medical students. Open Journal of Preventive Medicine, 3(06), 407-412

Ha, J. H., Chin, B., Park, D. H., Ryu, S. H. \& Yu, J. (2008). Characteristics of excessive cellular phone use in Korean adolescents. CyberPsychology \& Behavior, 11(6), 783-784.

J Kuss, D., D Griffiths, M., Karila, L. \& Billieux, J. (2014). Internet addiction: A systematic review of epidemiological research for the last decade. Current pharmacentical design, 20(25), 4026-4052.

Joiner, R., Gavin, J., Brosnan, M., Cromby, J., Gregory, H., Guiller, J., et. al. (2012). Gender, internet experience, internet identification, and internet anxiety: A ten-year followup. Cyberpsychology, Behavior and Social Networking, 15(7), 370-372.

Jun, W. (2015). An analysis study on correlation of internet addiction and smartphone addiction of teenagers. Paper presented at the Information Science and Security (ICISS), 2015 2nd International Conference on.

Kang, S. (2007). Disembodiment in online social interaction: Impact of online chat on social support and psychosocial well-being. CyberPsychology \& Behavior, 10(3), 475-477.

Kim, H. (2013). Exercise rehabilitation for smartphone addiction. Journal of Exercise Rehabilitation, 9(6), 500505. 
Yayan, E. H., Düken, M. E., Dağ , Y. S., \& Ulutaş, A. (2018). Examination of the relationship between nursing student's internet and smartphone addictions. Journal of Human Sciences, 15(2), 1161-1171. doi:10.14687/jhs.v15i2.5247

Kim, Y., Jeong, J.-E., Cho, H., Jung, D.-J., Kwak, M., Rho, M. J., et. al. (2016). Personality factors predicting smartphone addiction predisposition: Behavioral inhibition and activation systems, impulsivity, and self-control. PloS One, 11(8), e0159788.

King, A., Valença, A., Silva, A., Baczynski, T., Carvalho, M. \& Nardi, A. (2013). Nomophobia: Dependency on virtual environments or social phobia? Computers in Human Behavior, 29(1), 140144.

King, A. L. S., Valença, A. M., Silva, A. C., Sancassiani, F., Machado, S. \& Nardi, A. E. (2014). "Nomophobia": Impact of cell phone use interfering with symptoms and emotions of individuals with panic disorder compared with a control group. Clinical Practice \& Epidemiology in Mental Health, 10(1), 28-35

Koivusilta, L. K., Lintonen, T. P. \& Rimpelä, A. H. (2007). Orientations in adolescent use of information and communication technology: A digital divide by sociodemographic background, educational career, and health. Scandinavian Journal of Public Health, 35(1), 95-103.

Kwon, M., Lee, J. Y., Won, W. Y., Park, J. W., Min, J. A., Hahn, C., et. al. (2013). Development and validation of a smartphone addiction scale (SAS). PloS One, 8(2), e56936.

Lee, J. \& Seo, K. (2014). The comparison of cervical repositioning errors according to smartphone addiction grades. Journal of Physical Therapy Science, 26(4), 595-598.

Lin, F., Zhou, Y., Du, Y., Qin, L., Zhao, Z., Xu, J. \& Lei, H. (2012). Abnormal white matter integrity in adolescents with internet addiction disorder: A tract-based spatial statistics study. PloS One, 7(1), e30253.

Lin, Y. H., Chang, L. R., Lee, Y. H., Tseng, H. W., Kuo, T. B. \& Chen, S. H. (2014). Development and validation of the smartphone addiction inventory (SPAI). PloS One, 9(6), e98312.

Mittal, V. A., Tessner, K. D. \& Walker, E. F. (2007). Elevated social Internet use and schizotypal personality disorder in adolescents. Schizophrenia Research, 94(1), 50-57.

SecurEnvoy. (2012). 66\% of the population suffer from Nomophobia the fear of being without their phone (Vol. Erişim Tarihi 21.02.2017).

Şar, A. (2013). Examınation of loneliness and mobil phone addiction problem observed in teenagers from the some variables. International Journal of Social Science, 6(2), 1207-1220.

Tambağ, H. (2011). Hatay sağlık yüksekokulu öğrencilerinin sağlıklı yaşam biçimi davranışları ve etkileyen faktörler. Hacettepe Üniversitesi Hemşirelik Fakïltesi Dergisi, 18(2), 047-058.

Totten, J. W., Lipscomb, T. J., Cook, R. A. \& Lesch, W. (2005). General patterns of cell phone usage among college students: A four-state study. Services Marketing Quarterly, 26(3), 13-39.

Üneri, Ö. \& Tanıdır, C. (2011). Bir grup lise öğrencisinde internet bağımlılığı değerlendirmesi: Kesitsel bir çalışma. Düssïnen Adam Psikiyatri ve Nörolojik Bilimler Dergisi, 24(4), 265-272.

Valkenburg, P. M., Peter, J. \& Schouten, A. P. (2006). Friend networking sites and their relationship to adolescents' well-being and social self-esteem. CyberPsychology \& Behavior, 9(5), 584-590.

Yang, S. C. \& Tung, C.-J. (2007). Comparison of internet addicts and non-addicts in Taiwanese high school. Computers in Human Behavior, 23(1), 79-96.

Yang, Y. S., Yen, J. Y., Ko, C. H., Cheng, C. P. \& Yen, C.-F. (2010). The association between problematic cellular phone use and risky behaviors and low self-esteem among Taiwanese adolescents. BMC Public Health, 10(1), 217.

Yayan, E. H., Arikan, D., Saban, F., Gürarslan Baş, N. \& Özel Özcan, Ö. (2016). Examination of the correlation between internet addiction and social phobia in adolescents. Western Journal of Nursing Research, 39(9), 1240-1254

Yen, C. F., Tang, T. C., Yen, J. Y., Lin, H. C., Huang, C. F., Liu, S. C. \& Ko, C.-H. (2009). Symptoms of problematic cellular phone use, functional impairment and its association with depression among adolescents in Southern Taiwan. Journal of Adolescence, 32(4), 863-873.

Yen, J. Y., Ko, C. H., Yen, C. F., Chen, S. H., Chung, W. L. \& Chen, C. C. (2008). Psychiatric symptoms in adolescents with internet addiction: Comparison with substance use. Psychiatry and Clinical Neurosciences, 62(1), 9-16.

Yildirim, C. \& Correia, A. P. (2015). Exploring the dimensions of nomophobia: Development and validation of a self-reported questionnaire. Computers in Human Behavior, 49, 130-137.

Zheng, F., Gao, P., He, M., Li, M., Wang, C., Zeng, Q., et. al. (2014). Association between mobile phone use and inattention in 7102 Chinese adolescents: A population-based cross-sectional study. BMC Public Health, 14(1), 1022. 
Yayan, E. H., Düken, M. E., Dağ , Y. S., \& Ulutaş, A. (2018). Examination of the relationship between nursing student's internet and smartphone addictions. Journal of Human Sciences, 15(2), 1161-1171. doi:10.14687/jhs.v15i2.5247

\section{Tables:}

Table 1. Demographic Characteristics and Some Variables of Smartphone Usage

\begin{tabular}{|c|c|c|c|}
\hline \multirow[t]{2}{*}{ Age } & \multirow[t]{2}{*}{ Mean } & \multicolumn{2}{|c|}{$20.80 \pm 2.67$} \\
\hline & & $\mathrm{n}$ & $\%$ \\
\hline \multirow[t]{2}{*}{ Gender } & Female & 457 & 58.0 \\
\hline & Male & 331 & 42.0 \\
\hline \multirow[t]{2}{*}{ Sports habit } & Yes & 312 & 39.6 \\
\hline & No & 476 & 60.4 \\
\hline \multirow[t]{2}{*}{ Reading habit } & Yes & 604 & 76.6 \\
\hline & No & 184 & 23.4 \\
\hline \multirow[t]{2}{*}{ Phone with internet access } & Yes & 748 & 94.9 \\
\hline & No & 40 & 5.1 \\
\hline \multirow{2}{*}{$\begin{array}{l}\text { Behavior when the monthly } \\
\text { internet quota is exceeded }\end{array}$} & I wait for the next month & 520 & 66.0 \\
\hline & $\begin{array}{l}\text { I cut my expenditures to open the internet } \\
\text { access }\end{array}$ & 268 & 34.0 \\
\hline \multirow[t]{2}{*}{ Having a job } & Yes & 40 & 5.1 \\
\hline & No & 748 & 94.9 \\
\hline \multirow{3}{*}{$\begin{array}{l}\text { Behavior when the battery } \\
\text { runs out of charge }\end{array}$} & I use my phone after some charging & 172 & 21.8 \\
\hline & I use my phone while charging & 448 & 56.9 \\
\hline & I do not use my phone while charging & 168 & 21.3 \\
\hline \multirow{2}{*}{$\begin{array}{l}\text { Location of the phone while } \\
\text { sleeping }\end{array}$} & I keep my phone at an accessible distance & 648 & 82.2 \\
\hline & $\begin{array}{l}\text { I keep my phone at a non-accessible } \\
\text { distance }\end{array}$ & 140 & 17.8 \\
\hline \multirow{2}{*}{$\begin{array}{l}\text { Checking the phone first } \\
\text { thing in the morning }\end{array}$} & I check my phone first & 612 & 77.7 \\
\hline & I check my phone after morning routine & 176 & 22.3 \\
\hline \multirow{2}{*}{$\begin{array}{l}\text { Using the phone during } \\
\text { classes }\end{array}$} & Yes & 376 & 47.7 \\
\hline & No & 412 & 52.3 \\
\hline \multirow[t]{3}{*}{ Income level } & My income is less than my expenses & 208 & 26.4 \\
\hline & My income is equal to my expenses & 444 & 56.3 \\
\hline & My income is greater than my expenses & 136 & 17.3 \\
\hline
\end{tabular}


Yayan, E. H., Düken, M. E., Dağ , Y. S., \& Ulutaş, A. (2018). Examination of the relationship between nursing student's internet and smartphone addictions. Journal of Human Sciences, 15(2), 1161-1171. doi:10.14687/ihs.v15i2.5247

Table 2. Mean Scores on the Internet and Smartphone Addiction Scales and Subscales

\begin{tabular}{lccc}
\hline Internet Addiction Scale & Min. & Max. & Mean \pm SD \\
\hline Smartphone Addiction Scale & 28.00 & 118.00 & $68.60 \pm 21.56$ \\
\hline Disturbance of Daily Life and Tolerance & 33.00 & 167.00 & $90.58 \pm 29.44$ \\
\hline Withdrawal Symptoms & 8.00 & 47.00 & $23.38 \pm 9.18$ \\
\hline Positive Expectations & 7.00 & 42.00 & $18.02 \pm 8.01$ \\
\hline Cyber-Focused Relations & 5.00 & 30.00 & $16.32 \pm 5.39$ \\
\hline Overuse & 4.00 & 22.00 & $7.57 \pm 3.63$ \\
\hline Social Network Addiction & 4.00 & 24.00 & $11.53 \pm 4.96$ \\
\hline Physical Symptoms & 2.00 & 12.00 & $5.00 \pm 2.81$ \\
\hline
\end{tabular}

Table 3. Comparison of the Students' Demographic Characteristics and Their Mean Scores on the Internet and Smartphone Addiction Scales and Subscales

\begin{tabular}{|c|c|c|c|c|c|c|c|c|c|c|}
\hline & & IAS & SAS & $\begin{array}{l}\text { Disturbance of } \\
\text { Daily Life and } \\
\text { Tolerance }\end{array}$ & $\begin{array}{l}\text { Withdrawal } \\
\text { Symptoms }\end{array}$ & $\begin{array}{c}\text { Positive } \\
\text { Expectations }\end{array}$ & $\begin{array}{l}\text { Cyber- } \\
\text { Focused } \\
\text { Relations }\end{array}$ & Overuse & $\begin{array}{c}\text { Social } \\
\text { Network } \\
\text { Addiction }\end{array}$ & $\begin{array}{c}\text { Physical } \\
\text { Symptoms }\end{array}$ \\
\hline \multirow[t]{3}{*}{ Gender } & Female & $\begin{array}{c}71.63 \pm 21 \\
.17\end{array}$ & $\begin{array}{c}95.47 \pm \\
28.97\end{array}$ & $\begin{array}{c}24.53 \pm \\
8.99\end{array}$ & $\begin{array}{c}19.30 \pm \\
8.44\end{array}$ & $\begin{array}{l}17.04 \pm 4.9 \\
9\end{array}$ & $7.89 \pm 3.50$ & $\begin{array}{r}12.41 \\
\pm 5.00\end{array}$ & $\begin{array}{r}5.04 \pm \\
2.67\end{array}$ & $\begin{array}{r}9.23 \pm \\
3.42\end{array}$ \\
\hline & Male & $\begin{array}{c}64.41 \pm 21 \\
.43\end{array}$ & $\begin{array}{c}83.83 \pm \\
28.78\end{array}$ & $21.78 \pm 9.21$ & $16.25 \pm 7.03$ & $\begin{array}{c}15.34 \pm 5.7 \\
5\end{array}$ & $7.12 \pm 3.76$ & $\begin{array}{r}10.32 \\
\pm 4.64\end{array}$ & $\begin{array}{r}4.93 \pm \\
3.00\end{array}$ & $\begin{array}{r}8.07 \pm \\
3.58\end{array}$ \\
\hline & $\begin{array}{l}\mathrm{p} \\
\text { Test value* }\end{array}$ & $\begin{array}{l}0.000 \\
4.703\end{array}$ & $\begin{array}{l}0.000 \\
5.582\end{array}$ & $\begin{array}{l}0.000 \\
4.195\end{array}$ & $\begin{array}{l}0.000 \\
5.351\end{array}$ & $\begin{array}{l}0.000 \\
4.431\end{array}$ & $\begin{array}{l}0.003 \\
2.971\end{array}$ & $\begin{array}{l}0.000 \\
5.963\end{array}$ & $\begin{array}{l}0.574 \\
0.563\end{array}$ & $\begin{array}{l}0.000 \\
4.610\end{array}$ \\
\hline \multirow[t]{3}{*}{$\begin{array}{l}\text { Sports } \\
\text { habit }\end{array}$} & Yes & $\begin{array}{r}63.96 \pm 20 \\
.97\end{array}$ & $\begin{array}{r}85.70 \pm \\
29.35\end{array}$ & $\begin{array}{r}22.30 \pm \\
9.52\end{array}$ & $\begin{array}{r}17.11 \pm \\
6.99\end{array}$ & $\begin{array}{r}15.42 \\
\pm 6.05\end{array}$ & $\begin{array}{r}7.16 \pm \\
4.02\end{array}$ & $\begin{array}{r}10.44 \\
\pm 4.96\end{array}$ & $\begin{array}{r}4.92 \pm \\
3.11\end{array}$ & $\begin{array}{r}8.32 \pm \\
3.76\end{array}$ \\
\hline & No & $\begin{array}{r}71.64 \pm 21 \\
.43\end{array}$ & $\begin{array}{r}93.78 \pm \\
29.09\end{array}$ & $\begin{array}{r}24.08 \pm \\
8.88\end{array}$ & $\begin{array}{r}18.62 \pm \\
8.57\end{array}$ & $\begin{array}{r}16.92 \\
\pm 4.82\end{array}$ & $\begin{array}{r}7.84 \pm \\
3.32\end{array}$ & $\begin{array}{r}12.24 \\
\pm 4.83\end{array}$ & $\begin{array}{r}5.05 \pm \\
2.60\end{array}$ & $\begin{array}{r}9.02 \pm \\
3.34\end{array}$ \\
\hline & $\underset{\text { Test value* }}{\mathrm{p}}$ & $\begin{array}{c}0.00 \\
4.965\end{array}$ & $\begin{array}{l}0.000 \\
3.801\end{array}$ & $\begin{array}{l}0.008 \\
2.667\end{array}$ & $\begin{array}{l}0.010 \\
2.588\end{array}$ & $\begin{array}{l}0.000 \\
3.855\end{array}$ & $\begin{array}{l}0.011 \\
2.554\end{array}$ & $\begin{array}{c}0.00 \\
5.040\end{array}$ & $\begin{array}{l}0.536 \\
0.620\end{array}$ & $\begin{array}{c}0.06 \\
2.748\end{array}$ \\
\hline \multirow[t]{3}{*}{$\begin{array}{l}\text { Reading } \\
\text { habit }\end{array}$} & Yes & $\begin{array}{r}66.31 \pm 20 \\
.69\end{array}$ & $\begin{array}{r}88.60 \pm \\
28.34\end{array}$ & $\begin{array}{r}23.06 \pm \\
8.82\end{array}$ & $\begin{array}{r}17.41 \pm \\
7.73\end{array}$ & $\begin{array}{r}15.87 \\
\pm 5.44\end{array}$ & $\begin{array}{r}7.46 \pm \\
3.65\end{array}$ & $\begin{array}{r}11.31 \\
\pm 4.96\end{array}$ & $\begin{array}{r}4.84 \pm \\
2.82\end{array}$ & $\begin{array}{r}8.63 \pm \\
3.49\end{array}$ \\
\hline & No & $\begin{array}{r}76.13 \pm 22 \\
.68\end{array}$ & $\begin{array}{r}97.08 \pm \\
32.02\end{array}$ & $\begin{array}{r}24.41 \pm \\
10.23\end{array}$ & $\begin{array}{r}20.04 \pm \\
8.62\end{array}$ & $\begin{array}{r}17.82 \\
\pm 4.94\end{array}$ & $\begin{array}{r}7.93 \pm \\
3.55\end{array}$ & $\begin{array}{r}12.23 \\
\pm 4.92\end{array}$ & $\begin{array}{r}5.52 \pm \\
2.74\end{array}$ & $\begin{array}{r}9.10 \pm \\
3.64\end{array}$ \\
\hline & $\begin{array}{l}\mathrm{p} \\
\text { Test value* }\end{array}$ & $\begin{array}{c}0.00 \\
5.506\end{array}$ & $\begin{array}{l}0.001 \\
3.443\end{array}$ & $\begin{array}{l}0.081 \\
1.744\end{array}$ & $\begin{array}{c}0.00 \\
3.935\end{array}$ & $\begin{array}{c}0.00 \\
4.347\end{array}$ & $\begin{array}{l}0.124 \\
1.541\end{array}$ & $\begin{array}{l}0.027 \\
2.209\end{array}$ & $\begin{array}{l}0.004 \\
2.880\end{array}$ & $\begin{array}{l}0.112 \\
1.590\end{array}$ \\
\hline \multirow{4}{*}{$\begin{array}{l}\text { Behavior } \\
\text { when the } \\
\text { battery runs } \\
\text { out of } \\
\text { charge }\end{array}$} & $\begin{array}{l}\text { I use my phone } \\
\text { after some } \\
\text { charging }\end{array}$ & $\begin{array}{r}87.00 \pm 31 \\
.32\end{array}$ & $\begin{array}{r}65.55 \pm \\
22.89\end{array}$ & $\begin{array}{r}22.93 \pm \\
9.75\end{array}$ & $\begin{array}{r}17.81 \pm \\
7.99\end{array}$ & $\begin{array}{r}14.86 \\
\pm 5.23\end{array}$ & $\begin{array}{r}7.53 \pm \\
3.46\end{array}$ & $\begin{array}{r}10.95 \\
\pm 4.62\end{array}$ & $\begin{array}{r}4.83 \pm \\
2.57\end{array}$ & $\begin{array}{r}8.06 \pm \\
3.35\end{array}$ \\
\hline & $\begin{array}{l}\text { I use my phone } \\
\text { while charging }\end{array}$ & $\begin{array}{r}96.91 \pm 28 \\
.34\end{array}$ & $\begin{array}{r}74.85 \pm \\
19.33\end{array}$ & $\begin{array}{r}25.13 \pm \\
8.93\end{array}$ & $\begin{array}{r}19.08 \pm \\
8.11\end{array}$ & $\begin{array}{r}17.39 \\
\pm 4.98\end{array}$ & $\begin{array}{r}8.02 \pm \\
3.94\end{array}$ & $\begin{array}{r}12.57 \\
\pm 5.09\end{array}$ & $\begin{array}{r}5.47 \pm \\
2.95\end{array}$ & $\begin{array}{r}9.24 \pm \\
3.42\end{array}$ \\
\hline & $\begin{array}{l}\text { I do not use my } \\
\text { phone while } \\
\text { charging }\end{array}$ & $\begin{array}{r}77.38 \pm 25 \\
.18\end{array}$ & $\begin{array}{r}55.04 \pm \\
18.84\end{array}$ & $\begin{array}{r}19.16 \pm \\
7.74\end{array}$ & $\begin{array}{r}15.42 \pm \\
7.17\end{array}$ & $\begin{array}{r}15.00 \\
\pm 5.94\end{array}$ & $\begin{array}{r}6.40 \pm \\
2.52\end{array}$ & $\begin{array}{r}9.35 \pm \\
4.09\end{array}$ & $\begin{array}{r}3.90 \pm \\
2.33\end{array}$ & $\begin{array}{r}8.11 \pm \\
3.79\end{array}$ \\
\hline & $\begin{array}{l}\mathrm{p} \\
\text { Test value** }\end{array}$ & $\begin{array}{c}0.00 \\
30.684\end{array}$ & $\begin{array}{c}0.00 \\
62.059\end{array}$ & $\begin{array}{c}0.00 \\
27.855\end{array}$ & $\begin{array}{c}0.00 \\
13.138\end{array}$ & $\begin{array}{c}0.00 \\
21.236\end{array}$ & $\begin{array}{c}0.00 \\
12.541\end{array}$ & $\begin{array}{c}0.00 \\
29.041\end{array}$ & $\begin{array}{c}0.00 \\
20.214\end{array}$ & $\begin{array}{c}0.00 \\
10.424\end{array}$ \\
\hline
\end{tabular}


1170

Yayan, E. H., Düken, M. E., Dağ , Y. S., \& Ulutaş, A. (2018). Examination of the relationship between nursing student's internet and smartphone addictions. Journal of Human Sciences, 15(2), 1161-1171. doi:10.14687/ihs.v15i2.5247

\begin{tabular}{|c|c|c|c|c|c|c|c|c|c|c|}
\hline \multirow[t]{4}{*}{$\begin{array}{l}\text { Income } \\
\text { level }\end{array}$} & $\begin{array}{l}\text { My income is } \\
\text { less than my } \\
\text { expenses }\end{array}$ & $\begin{array}{r}100.15 \pm 2 \\
9.54\end{array}$ & $\begin{array}{r}73.17 \pm \\
21.44\end{array}$ & $\begin{array}{r}26.01 \pm \\
8.60\end{array}$ & $\begin{array}{r}20.40 \pm \\
8.17\end{array}$ & $\begin{array}{r}16.55 \\
\pm 5.44\end{array}$ & $\begin{array}{r}9.03 \pm \\
3.78\end{array}$ & $\begin{array}{r}13.00 \\
\pm 5.01\end{array}$ & $\begin{array}{r}5.73 \pm \\
2.94\end{array}$ & $\begin{array}{r}9.40 \pm \\
3.23\end{array}$ \\
\hline & $\begin{array}{l}\text { My income is } \\
\text { equal to my } \\
\text { expenses }\end{array}$ & $\begin{array}{r}87.97 \pm 27 \\
.78\end{array}$ & $\begin{array}{r}68.31 \pm \\
21.22\end{array}$ & $\begin{array}{r}22.54 \pm \\
9.01\end{array}$ & $\begin{array}{r}17.53 \pm \\
7.40\end{array}$ & $\begin{array}{r}16.21 \\
\pm 5.26\end{array}$ & $\begin{array}{r}7.19 \pm \\
3.41\end{array}$ & $\begin{array}{r}11.18 \\
\pm 4.71\end{array}$ & $\begin{array}{r}4.97 \pm \\
2.75\end{array}$ & $\begin{array}{r}8.32 \pm \\
3.58\end{array}$ \\
\hline & $\begin{array}{l}\text { My income is } \\
\text { greater than my } \\
\text { expenses }\end{array}$ & $\begin{array}{r}84.50 \pm 31 \\
.33\end{array}$ & $\begin{array}{r}62.55 \pm \\
21.41\end{array}$ & $\begin{array}{r}22.08 \pm \\
9.82\end{array}$ & $\begin{array}{r}16.00 \pm \\
8.88\end{array}$ & $\begin{array}{r}16.35 \\
\pm 5.76\end{array}$ & $\begin{array}{r}6.55 \pm \\
3.46\end{array}$ & $\begin{array}{r}10.41 \\
\pm 5.21\end{array}$ & $\begin{array}{r}3.97 \pm \\
2.51\end{array}$ & $\begin{array}{r}9.11 \pm \\
3.64\end{array}$ \\
\hline & $\begin{array}{l}\mathrm{p} \\
\text { Test value** }\end{array}$ & $\begin{array}{c}0.00 \\
16.238\end{array}$ & $\begin{array}{c}0.00 \\
10.285\end{array}$ & $\begin{array}{c}0.00 \\
12.131\end{array}$ & $\begin{array}{c}0.00 \\
14.832\end{array}$ & $\begin{array}{l}0.752 \\
0.285\end{array}$ & $\begin{array}{c}0.00 \\
26.141\end{array}$ & $\begin{array}{c}0.00 \\
14.067\end{array}$ & $\begin{array}{c}0.00 \\
16.714\end{array}$ & $\begin{array}{l}0.001 \\
7.637\end{array}$ \\
\hline & & IAS & SAS & $\begin{array}{l}\text { Disturbance of } \\
\text { Daily Life and } \\
\text { Tolerance }\end{array}$ & $\begin{array}{l}\text { Withdrawal } \\
\text { Symptoms }\end{array}$ & $\begin{array}{c}\text { Positive } \\
\text { Expectations }\end{array}$ & $\begin{array}{l}\text { Cyber- } \\
\text { Focused } \\
\text { Relations }\end{array}$ & Overuse & $\begin{array}{c}\text { Social } \\
\text { Network } \\
\text { Addiction }\end{array}$ & $\begin{array}{l}\text { Physical } \\
\text { Symptoms }\end{array}$ \\
\hline \multirow{3}{*}{$\begin{array}{l}\text { Behavior } \\
\text { when the } \\
\text { monthly } \\
\text { internet } \\
\text { quota is } \\
\text { exceeded }\end{array}$} & $\begin{array}{l}\text { I wait for the } \\
\text { next month }\end{array}$ & $\begin{array}{r}61.83 \pm 1 \\
8.89\end{array}$ & $\begin{array}{r}84.26 \pm 27 \\
.54\end{array}$ & $\begin{array}{r}21.94 \pm \\
8.89\end{array}$ & $\begin{array}{r}16.51 \\
\pm 7.16\end{array}$ & $\begin{array}{r}15.60 \\
\pm 5.36\end{array}$ & $\begin{array}{r}6.97 \pm 3 \\
.01\end{array}$ & $\begin{array}{r}10.37 \\
\pm 4.47\end{array}$ & $\begin{array}{r}4.51 \pm \\
2.56\end{array}$ & $\begin{array}{r}8.29 \pm \\
3.44\end{array}$ \\
\hline & $\begin{array}{l}\text { I cut my } \\
\text { expenditures to } \\
\text { open the } \\
\text { internet access }\end{array}$ & $\begin{array}{r}81.74 \pm 2 \\
0.35\end{array}$ & $\begin{array}{r}102.94 \pm 2 \\
9.13\end{array}$ & $\begin{array}{r}26.16 \pm \\
9.09\end{array}$ & $\begin{array}{r}20.95 \\
\pm 8.75\end{array}$ & $\begin{array}{r}17.74 \\
\pm 5.16\end{array}$ & $\begin{array}{r}8.73 \pm 4 \\
.38\end{array}$ & $\begin{array}{r}13.77 \\
\pm 5.10\end{array}$ & $\begin{array}{r}5.94 \pm \\
3.04\end{array}$ & $\begin{array}{r}9.62 \pm \\
3.55\end{array}$ \\
\hline & $\begin{array}{l}\mathrm{P} \\
\text { Test value* }\end{array}$ & $\begin{array}{c}0.00 \\
13.648\end{array}$ & $\begin{array}{c}0.00 \\
8.860\end{array}$ & $\begin{array}{c}0.00 \\
6.256\end{array}$ & $\begin{array}{c}0.00 \\
7.625\end{array}$ & $\begin{array}{c}0.00 \\
5.386\end{array}$ & $\begin{array}{c}0.00 \\
6.591\end{array}$ & $\begin{array}{c}0.00 \\
9.621\end{array}$ & $\begin{array}{c}0.00 \\
6.918\end{array}$ & $\begin{array}{c}0.00 \\
5.099\end{array}$ \\
\hline \multirow[t]{2}{*}{$\begin{array}{l}\text { Location } \\
\text { of the } \\
\text { phone } \\
\text { while } \\
\text { sleeping }\end{array}$} & $\begin{array}{l}\text { I keep my } \\
\text { phone at an } \\
\text { accessible } \\
\text { distance }\end{array}$ & $\begin{array}{r}70.72 \pm 2 \\
1.21\end{array}$ & $\begin{array}{r}93.81 \pm 29 \\
.49\end{array}$ & $\begin{array}{r}24.20 \pm \\
9.18\end{array}$ & $\begin{array}{r}18.54 \\
\pm 8.21\end{array}$ & $\begin{array}{r}16.87 \\
\pm 5.30\end{array}$ & $\begin{array}{r}7.72 \pm 3 \\
.83\end{array}$ & $\begin{array}{r}12.15 \\
\pm 4.98\end{array}$ & $\begin{array}{r}5.19 \pm \\
2.89\end{array}$ & $\begin{array}{r}9.11 \pm \\
3.48\end{array}$ \\
\hline & $\begin{array}{l}\mathrm{P} \\
\text { Test value* }\end{array}$ & $\begin{array}{c}0.00 \\
6.064\end{array}$ & $\begin{array}{c}0.00 \\
6.804\end{array}$ & $\begin{array}{c}0.00 \\
5.514\end{array}$ & $\begin{array}{c}0.00 \\
3.935\end{array}$ & $\begin{array}{c}0.00 \\
6.269\end{array}$ & $\begin{array}{l}0.010 \\
2.582\end{array}$ & $\begin{array}{c}0.00 \\
7.844\end{array}$ & $\begin{array}{c}0.00 \\
4.141\end{array}$ & $\begin{array}{c}0.00 \\
6.503\end{array}$ \\
\hline \multirow{3}{*}{$\begin{array}{l}\text { Checking } \\
\text { the phone } \\
\text { first thing } \\
\text { in the } \\
\text { morning }\end{array}$} & $\begin{array}{l}\text { I check my } \\
\text { phone first }\end{array}$ & $\begin{array}{r}73.21 \pm 2 \\
0.16\end{array}$ & $\begin{array}{r}97.42 \pm 27 \\
.72\end{array}$ & $\begin{array}{r}25.45 \pm \\
8.71\end{array}$ & $\begin{array}{r}19.46 \\
\pm 7.91\end{array}$ & $\begin{array}{r}17.07 \\
\pm 5.22\end{array}$ & $\begin{array}{r}7.98 \pm 3 \\
.81\end{array}$ & $\begin{array}{r}12.53 \\
\pm 4.82\end{array}$ & $\begin{array}{r}5.53 \pm \\
2.88\end{array}$ & $\begin{array}{r}9.37 \pm \\
3.39\end{array}$ \\
\hline & $\begin{array}{l}\text { I check my } \\
\text { phone after } \\
\text { morning routine }\end{array}$ & $\begin{array}{r}52.56 \pm 1 \\
8.43\end{array}$ & $\begin{array}{r}66.81 \pm 21 \\
.98\end{array}$ & $\begin{array}{r}16.15 \pm \\
6.80\end{array}$ & $\begin{array}{r}13.02 \\
\pm 6.15\end{array}$ & $\begin{array}{r}13.75 \\
\pm 5.16\end{array}$ & $\begin{array}{r}6.15 \pm 2 \\
.45\end{array}$ & $\begin{array}{r}8.04 \pm \\
3.70\end{array}$ & $\begin{array}{r}3.13 \pm \\
1.49\end{array}$ & $\begin{array}{r}6.54 \pm \\
3.10\end{array}$ \\
\hline & $\begin{array}{l}\mathrm{P} \\
\text { Test value* }\end{array}$ & $\begin{array}{c}0.00 \\
12.197\end{array}$ & $\begin{array}{c}0.00 \\
13.474\end{array}$ & $\begin{array}{c}0.00 \\
13.054\end{array}$ & $\begin{array}{c}0.00 \\
9.960\end{array}$ & $\begin{array}{c}0.00 \\
7.447\end{array}$ & $\begin{array}{c}0.00 \\
5.988\end{array}$ & $\begin{array}{c}0.00 \\
11.410\end{array}$ & $\begin{array}{c}0.00 \\
10.636\end{array}$ & $\begin{array}{c}0.00 \\
9.935\end{array}$ \\
\hline \multirow{3}{*}{$\begin{array}{l}\text { Using the } \\
\text { phone } \\
\text { during } \\
\text { classes }\end{array}$} & Yes & $\begin{array}{r}75.77 \pm 2 \\
1.81\end{array}$ & $\begin{array}{r}96.59 \pm 32 \\
.07\end{array}$ & $\begin{array}{r}25.02 \pm \\
10.34\end{array}$ & $\begin{array}{r}19.53 \\
\pm 8.83\end{array}$ & $\begin{array}{r}17.03 \\
\pm 5.40\end{array}$ & $\begin{array}{r}7.74 \pm 3 \\
.76\end{array}$ & $\begin{array}{r}12.81 \\
\pm 5.12\end{array}$ & $\begin{array}{r}5.45 \pm \\
3.07\end{array}$ & $\begin{array}{r}8.98 \pm \\
3.66\end{array}$ \\
\hline & No & $\begin{array}{r}62.05 \pm 1 \\
9.14\end{array}$ & $\begin{array}{r}85.10 \pm 25 \\
.65\end{array}$ & $\begin{array}{r}21.88 \pm \\
7.68\end{array}$ & $\begin{array}{r}16.65 \\
\pm 6.92\end{array}$ & $\begin{array}{r}15.68 \\
\pm 5.30\end{array}$ & $\begin{array}{r}7.41 \pm 3 \\
.51\end{array}$ & $\begin{array}{r}10.35 \\
\pm 4.50\end{array}$ & $\begin{array}{r}4.58 \pm \\
2.48\end{array}$ & $\begin{array}{r}8.52 \pm \\
3.39\end{array}$ \\
\hline & $\begin{array}{l}\mathrm{P} \\
\text { Test value* }\end{array}$ & $\begin{array}{c}0.00 \\
9.399\end{array}$ & $\begin{array}{c}0.00 \\
5.574\end{array}$ & $\begin{array}{c}0.00 \\
4.861\end{array}$ & $\begin{array}{c}0.00 \\
5.118\end{array}$ & $\begin{array}{c}0.00 \\
3.516\end{array}$ & $\begin{array}{l}0.207 \\
1.263\end{array}$ & $\begin{array}{c}0.00 \\
7.166\end{array}$ & $\begin{array}{c}0.00 \\
4.401\end{array}$ & $\begin{array}{l}0.065 \\
1.847\end{array}$ \\
\hline
\end{tabular}


Yayan, E. H., Düken, M. E., Dağ , Y. S., \& Ulutaş, A. (2018). Examination of the relationship between nursing student's internet and smartphone addictions. Journal of Human Sciences, 15(2), 1161-1171. doi:10.14687/jhs.v15i2.5247

Table 4. Correlation of the Internet Addiction Scale and the Subscales of the Smartphone Addiction Scale

\begin{tabular}{|c|c|c|}
\hline & & $\begin{array}{c}\text { Internet Addiction } \\
\text { Scale }\end{array}$ \\
\hline \multirow{2}{*}{$\begin{array}{l}\text { Disturbance of Daily Life and } \\
\text { Tolerance }\end{array}$} & $\mathrm{r}$ & $.716^{* *}$ \\
\hline & $\mathrm{p}$ & .000 \\
\hline \multirow[t]{2}{*}{ Withdrawal Symptoms } & $\mathrm{r}$ & $.592^{* *}$ \\
\hline & $\mathrm{p}$ & .000 \\
\hline \multirow[t]{2}{*}{ Positive Expectations } & $\mathrm{r}$ & $.508^{* *}$ \\
\hline & $\mathrm{p}$ & .000 \\
\hline \multirow[t]{2}{*}{ Cyber-Focused Relations } & $\mathrm{r}$ & $.380^{* *}$ \\
\hline & $\mathrm{p}$ & .000 \\
\hline \multirow[t]{2}{*}{ Overuse } & $\mathrm{r}$ & $.628^{* *}$ \\
\hline & $\mathrm{p}$ & .000 \\
\hline \multirow[t]{2}{*}{ Social Network Addiction } & $\mathrm{r}$ & $.484^{* *}$ \\
\hline & $\mathrm{p}$ & .000 \\
\hline \multirow[t]{2}{*}{ Physical Symptoms } & $\mathrm{r}$ & $.515^{* *}$ \\
\hline & $\mathrm{p}$ & .000 \\
\hline \multirow[t]{2}{*}{ Smartphone Addiction Scale } & $\mathrm{r}$ & $.739^{* *}$ \\
\hline & $\mathrm{p}$ & .000 \\
\hline
\end{tabular}

